\title{
CONSULAR COOPERATION IN THIRD STATES: SOME ASPECTS CONCERNING EUROPANISATION OF FOREIGN SERVICE FOR EU CITIZENS ${ }^{1}$
}

\author{
Erzsébet Csatlós \\ University of Szeged, Faculty of Law and Political Sciences
}

\begin{abstract}
The EU does not aim to harmonize the public administration of Member States, although, in recent years, there have been several examples which prove that EU legislation in whatever policy inevitably and unavoidably results in some standardization. In 2015 the EU replaced its former decision with a directive to enhance Member States to co-ordinate consular assistance in third States. Every EU citizen has the right to enjoy, in the territory of a third State in which the Member State of which they are nationals is not represented, the protection of the diplomatic and consular authorities of any Member State on the same conditions as the nationals of that State. This provision of Article 23 of TFEU not solely requires the cooperation of administrative authorities of foreign service but implicitly means a kind of harmonization of substantive law, leads to organizational changes and affects administrative procedural rules of Member States.
\end{abstract}

Key words: consular relations, administrative law, cooperation of administrative authorities, EEAS

\section{CONSULAR PROTECTION}

People travelling, living or trading beyond the borders of their homeland could have always benefitted a kind of care from their country of origin as the specific link called nationality between the person and the State remains and reciprocally obliges both parties even beyond state borders. ${ }^{2}$ This legal relationship is older than the concept of modern State. Foreign Service is the prolongation of a few administrative functions of the State on the territory of another State. It has two main directions: diplomacy primarily serves the interest of the sending State while promoting friendly relations and consular service is to help and serve the citizens there with the consent of the latter, the receiving State. Consular protection is help, advice and the possibility to handle official matters of an administrative nature by the consular or diplomatic agents of a country to citizens of that country who are living or just staying abroad. It has always been a discretional right of the State to decide upon the subject and the scope and extent of this kind of service.

Every state defines the scope of the functions of its consular representatives, considering the legislation of the host country. The main sources of consular law therefore are the many consular agreements concluded by individual countries defining the legal status of consuls and laying down the basic rules under which they function. As for the service given for nationals, it has two main

1 „SUPPORTED BY THE UNKP-17-4-III-SZTE-10. NEW NATIONAL EXCELLENCE PROGRAM OF THE MINISTRY OF HUMAN CAPACITIES".

2 AUST, A.: Handbook of International Law. Cambridge: CUP, 2010, p. 42.; SLOANE, R. D.: Breaking the Genuine Link: The Contemporary International Legal Regulation of Nationality. In: Harvard International Law Journal, vol. 50, No. 1, 2009, p. $29-33$. 
areas. A part of consular service can be regarded as an outsourced version of domestic administration, for example the possibility of getting travel documents, so it is regulated solely by the laws of the sending state. The other part rather aims to help and protect citizens' interest on the territory of a foreign State, for example in case of detention, it is good to have somebody who can help with knowing local conditions and get professional legal help. In such cases, the scope of procedural rights and possibilities of the consul is basically up to the laws of the receiving State and the agreement of the States concerned.

Consular assistance and protection is a service of domestic competence, ${ }^{3}$ so is the public administration of Member States to which the consular and diplomatic representation is an extra territorial organizational unit performing administrative authority functions among others, therefore it shall be strictly examined what is exactly required by EU law.

\section{ASPECTS OF COOPERATION OF CONSULAR AUTHORITIES}

\subsection{Consular protection and EU legislative competences}

The concept of EU citizenship exists since the entry into force of the Maastricht Treaty in $1993 .{ }^{4}$ It creates a specific relationship to strengthen European identity while it guarantees the right to any EU citizen in a non-EU country where his/her own national state has no representation to ask for protection by the diplomatic or consular authorities of any other EU country. The concept is to strengthen the sense of togetherness and the feeling of being a part of one unified European nation, on the basis of solidarity and loyalty among EU 28 and in the light of non-discrimination and legal equality. ${ }^{5}$ As a matter of fact, Member States are all present in only three countries: the US, Russia and China ${ }^{6}$ but the need for consular help is increasing in our world of natural disasters and terrorist acts, so the concept of equally providing for help for EU citizens where their State of nationality is not represented or not available is useful and has a growing relevance as there is a tendency of closing foreign services to cut expenses.

Following the Maastricht Treaty, the European Community's decision with its six meaningful articles of nine entered into force in 2002 (95/553/EC) on details of diplomatic protection ${ }^{7}$ and a decision on the establishment of an emergency travel document (96/409/CFSP) was adopted along with non-binding guidelines on consular protection and the concept of lead state of coop-

3 CARE Final Report. Consular and Diplomatic Protection. Legal Framework in the EU Member States. 2010. http://www. careproject.eu/images/stories/ConsularAndDiplomaticProtection.pdf, p. 665; VERMEER-KÜNZLI, A: Where the Law Becomes Irrelevant: Consular Assistance and the European Union. In: International and Comparative Law Quarterly, 2011, vol. 60, p. 971.

4 Maastricht Treaty, Art. 8c.; currently Article 23 TFEU (ex Article 20 TEC, Treaty on the European Community).

5 GEYER, F.: The External Dimension of EU Citizenship. Arguing for Effective Protection of Citizens Abroad. CEPS, No. 136. July 2007, p. 2.

6 Green Paper: Diplomatic and consular protection of Union citizens in third countries. Brussels, 28.11.2006, $\operatorname{COM}(2006) 712$ final, p. 4. point 1.5.; BALFOUR, R. - RAIK, K.: Equipping the European Union for the 21st century. National diplomacies, the European External Action Service and the making of EU foreign policy. FIIA Report 36, 2013, p. 12.

7 Council Decision of 1995. Decision of the Representatives of the Governments of the Member States meeting within the Council of 19 December 1995 regarding protection for citizens of the European Union by diplomatic and consular representations. OJ L 314 , 28/12/1995, pp. 73 - 76. 
eration. ${ }^{8}$ These documents were not recognized as part of the EU legal order, as they were adopted by Member States governments and not by the institutions however as acquis communautaire they were to be respected. ${ }^{9}$ At that time the field of consular and diplomatic cooperation was purely an inter-governmental area of Community legislation, it could not overcome the diversity of national regulations and foreign policies. Since the Maastricht Treaty citizens were entitled to receive consular protection, but this provision rather reflected a non-discrimination clause than an individual right for citizens and an obligation for States under all circumstances, since consular protection is just the possibility of State under general international law, not an obligation to fulfil.

Everything has changed when the EU Charter became a primary source by the Treaty of Lisbon - EU citizens' rights to diplomatic and consular protection echoed in Article $46^{10}$ was reappraised as a fundamental right. Consular protection has become an integral part of the Union's policy on citizens' rights, ${ }^{11}$ by the abolition of pillars it was placed under the scope of the EU and the Court of Justice of the EU, and the Council also got the right to regulate related questions in the form of directives adopted in a specific legislative procedure. The concept also changed: the Council, acting in accordance with a special legislative procedure and after consulting the European Parliament, adopted directives establishing the coordination and cooperation measures necessary to facilitate such protection, ${ }^{12}$ and within the provisions of external actions of the EU, ordered the establishment of the European External Action Service, and as diplomatic mission of the integration, the apparatus of $E U$ delegations in third countries and at international organizations was introduced to represent the EU and to act in close cooperation with Member States' diplomatic and consular services. ${ }^{13}$ The question is what it means for Member States under specific competency rules and decision-making system. ${ }^{14}$ The implementation deadline of the directive is 1 May 2018, however, it leaves some open questions which may not be answered by domestic legislations in a uniform manner.

Consular service is an extra territorial branch of State administration heavily related to foreign policy of the State and inter-state relations, which is still a sensible area even after Lisbon. Consular assistance consists of actions, often performed by authority measures, therefore consular policy has relatively strong relation to administration. As a matter of fact, EU's legislative competence is only to support, coordinate or supplement the actions of the Member States to improve their administrative capacity for a better implementation of EU law. The legislative acts shall not result in any harmonization of the national administrative laws. ${ }^{15}$ It does not mean that EU law has no influence on administration, but effective execution and implementation of EU policy is the responsibility of Member States, so the necessary harmonization in administration issues is a domestic competence. The question is to find the limit between the necessary modification to realize and achieve common policies and the implicit expansion of EU competences; even the preamble of the consular directive

8 KRŪMA, K.: EU Citizenship, Nationality and Migrant Status: an Ongoing Challenge. Leiden: Martinus Nijhoff Publishers, 2013, p. 170.

9 CARE Final Report, pp. 24-25.

10 „Every citizen of the Union shall, in the territory of a third country in which the Member State of which he or she is a national is not represented, be entitled to protection by the diplomatic or consular authorities of any Member State, on the same conditions as the nationals of that Member State."

11 Proposal for a Council Directive on consular protection for citizens of the Union abroad, 1.2.; p. 2.

12 Treaty of Lisbon, point 36.

13 Treaty of Lisbon, point 30) on the new Article 13a; Article $188 \mathrm{Q}$ on delegations.

14 See TEU Title V. especially Article 22 and Articles 29-31.

15 TFEU Article 2.5.; 6 (g); and 197. 
set the limitation of its scope: it does not affect consular relations between Member States and third countries, their rights and obligations arising from international customs and agreements.

\subsection{Consular directive and Member State obligations: "cooperation and coordination measures to facilitate ..."}

The directive obliges Member States and does not limit the scope of authorities: it leaves the question open for Member States as to all types of extra-territorial representations, since this depends on the habits and regulations of States to decide upon which organ to authorize to provide consular assistance. Although the text mentions diplomatic and consular protection, the relevant provisions and also legal literature is in agreement that the obligation refers to measures of consular assistance even if it is performed by diplomatic agents in the absence of consuls. ${ }^{16}$ Citizens of the EU should be considered to be unrepresented in a third country if their Member State of nationality has no embassy, consulate ${ }^{17}$ or honorary consul established there, or if the body is unable for any reason to provide, in a given case, the protection or it is just unavailable for the citizen for distance or any other reasons or circumstances. ${ }^{18}$ This possibility is also equally open for the non-EU citizen family members ${ }^{19}$; however, some restrictions might indicate different treatment as emergency travel documents (EDT) can only be issued for EU citizens, for example. ${ }^{20}$ As for identification of the citizenship and family ties, the rules are relatively flexible if the persons are unable to produce valid passports or identity cards. Nationality may be proven by any other means, if necessary including verification with the diplomatic or consular authorities of the Member State of which the applicant claims to be a national. ${ }^{21}$

As a matter of fact, in case of non-national EU citizens, apart from extreme cases, consular authorities do not proceed ex officio, consular protection needs to be claimed. However, when the

16 Consular functions can be exercised by diplomatic missions in accordance with the provisions of the general international rules of consular and diplomatic relations. VCDR, Article 3.2.; VCCR Article 3.; 70. BATTINI, S.: The Impact of EU Law and Globalization on Consular Assistance and Diplomatic Protection. CHITI, E. - MATTARELLA, B.G. (eds.): Global Administrative Law and EU Administrative Law. Berlin, Heidelberg: Springer-Verlag, 2011, p. 177-178.; SCHIFFNER, I.: A diplomáciai védelem gyakorlásának eszközei, avagy a fogalom-meghatározás és az elhatárolás problémái. In: Acta Universitatis Szegediensis de Attila József Nominatae Sectio Juridica Politica, Tom. LXXII. Fasc. 18, 2009, p. 535- 543; BECÁNICS, A.: Konzuli védelem és segítségnyújtás az Európai Unió perspektívájából. KARLOVITZ, J. T. (ed.): Fejlődő jogrendszer és gazdasági környezet a változó társadalomban. 2014. http://www.irisro.org/tarstud2015aprilis/index.html (02.09.2016.), p. 25-26.

17 The exercise of consular functions does not always mean that the consular service is established on the territory of the State in question. The sending State may, after notifying the States concerned, entrust a consular post established in a State with the exercise of consular functions in another State, unless there is express objection by one of the States concerned (exercise of consular functions in a third State, VCCR, Article 7.). Another solution to the representation is the agreement with a State who already has a consular service in the State concerned to provide for consular protection to citizens of both States. Upon appropriate notification to the receiving State, a consular office of the sending State may, unless the receiving State objects, exercise consular functions in the receiving State on behalf of a third State (exercise of consular functions on behalf of a third State, VCCR, Article 8).

18 Consular directive, (8); Article 6.

19 The right to respect for private and family life is acknowledged by Article 7 of the EU Charter and the family reunification principle also serves the private life of citizens. However, the EU family reunification principle has a narrow scope of family members, see: Directive on family reunification, Article 4. However, the more favourable treatment clause is also to be applied for the meaning of family member. Consular directive, Article 16.

20 Consular directive, (8); EDT Decision, Annex II. 2. (a).

21 Consular directive, Article 8. 
consular authority is aware of the need of consular protection, especially in case of travel documents, the family reunification principle ${ }^{22}$ may require some positive action like promoting the contacting between the family members and its Foreign Ministry. Over and above, article 23 and the Consular Directive detailing its content exceeded former 'non-discrimination clause' notion and shifted the emphasis to the coordination and cooperation of consular authorities from the simple declaration of the right to consular protection which characterized the previous regime.

The intent of the Consular Directive is to guarantee help and protection in Third States by creating an obligation for consular authorities to coordinate their acts and cooperate with each other while fulfilling the required obligation and taking the necessary measures if the consular authority of nationality (citizenship) is not able to do so. ${ }^{23}$ So, it is not required from States to renounce their discretionary right ${ }^{24}$ to provide for consular protection, and diplomatic and consular authorities of the Member States are not legally obliged to satisfy all the requests for assistance from EU citizens. But it does mean first, to help citizens to get the assistance needed by his/her own national consular authorities and if it is not possible or it is unable to act, secondly, provide for the necessary consular protection. Indeed, when a Member State receives a request for consular protection from a person who claims to be an unrepresented EU citizen, or is informed of an individual emergency of an unrepresented citizen, it shall consult without delay the Ministry of Foreign Affairs of the Member State of which the person claims to be a national or, where appropriate, the competent embassy or consulate of that Member State, and provide it with all the relevant information at its disposal. This notification includes the identity of the person concerned, possible costs of consular protection, and information on any family members to whom consular protection may also need to be provided and helps and facilitates the exchange of information between the citizen concerned and the authorities of the citizen's Member State of nationality. As for the preparation for a more comprehensive work, local cooperation meetings are held for a regular exchange of information on matters relevant to unrepresented citizens. It is chaired by one of the Member State representatives and it is in close cooperation with the delegation of the $\mathrm{EU}$, if there is any. ${ }^{25}$

Except in cases of extreme urgency, this consultation shall take place before assistance is provided. ${ }^{26}$ The obligation therefore primarily refers to being available for EU citizens without representation and the notification to their own State to make it possible that they get the requested protection and assistance by their State. This does not require the acting of the consul, but rather the exchange of information and cooperation during normal times and, above all, during major crises. The need for an active consular cooperation is not just theory as an estimated $8.7 \%$ of EU citizens, or 7 million people, travel outside the EU to States where their Member State is not represented and a further 2 million EU citizens live in such countries. ${ }^{27}$ A survey of 2015 states that $7 \mathrm{EU}$ citizens from 10 are

22 Member States are required to adopt measures for family reunification concerning residency cases of third country nationals in conformity with the obligation to protect the family and respect family life enshrined in many instruments of international law and in respect of the fundamental rights recognized in Article 8 of the EU Charter. Directive on family reunification, preamble (2).

A. Where the Law Becomes Irrelevant, p. 969.

practice of Member States is various regarding their attitude to consular protection: whether it is a duty of the State or a discretionary right to decide upon providing for it. SCHIFFNER, I.: Az uniós polgárok konzuli védelmének lehetőségei Consular Directive, Article 12

26 Consular Directive, Article 10.

$27 \operatorname{COM(2009)} 263$ final III.1.2, p. 5 
aware of the right to turn to the representative of any Member States if his or her State is not represented in a third State. ${ }^{28}$

As for the scope of help, the directive, in line with the former decision, does not create new functions for representatives of Member States; although it enlists some typical cases in which consular protection shall be available for all EU citizens in third States: death, serious accident or serious illness, arrest or detention, falling victim of violent crime, loss or theft of identity documents, and situations requiring repatriation or relief especially in armed conflicts, and in case of natural disasters. ${ }^{29}$ The measure taken in such cases is up to the consular law of Member States, which is also free to ensure a wider range of protection but it shall be equally available for nationals and for non-nationals (EU citizens). ${ }^{30}$ With regard to the nature of the help, according to the latest Eurobarometer survey on the topic done in 2006, arrangement to immediately return to home was the most preferred form of assistance Europeans would like to have in emergency. The Eurobarometer survey published in 2006 states one third (33\%) of the overall EU25 population mentioned this as their first preference. ${ }^{31}$ In 2016, the statistics of the EEAS show that the number of non-represented EU citizens requesting consular assistance is limited and the cases are manageable; most requests deal with loss of travel documents. ${ }^{32}$

As for travel documents, only the national authorities can replace the damaged, lost or stolen ones, for non-national EU citizens the ETD can be issued upon request which is valid slightly longer than the minimum time needed to complete the journey for which it is issued. ${ }^{33}$ It also requires the collaboration of the national authorities as the ETD can only be issued if clearance from the authorities of the person's Member State of origin has been obtained. Problems might occur with non-represented non-EU citizen family members. They are not entitled to get an ETD and this makes the return to home impossible for the family as it is obvious that they will not split up. Consular Directive does not directly create obligation for the consular authority proceeding in the case of the citizen to contact the national authorities of the non-citizen's Member State for that purpose. However, the general rules obliging Member State consular authorities to provide consular protection to the same extent and on the same conditions as the EU citizen ${ }^{34}$ can be interpreted to that way to reach this conclusion. As for practical guidance to travel home, its form is up to the situation but concerning financial help, rules are clear: it is a final solution and national and non-national consular authority is also obliged to give financial help with the same conditions as to their nationals. Except for crisis, citizen shall sign an undertaking to repay to his or her Member State of nationality

28 Flash Eurobarometer \#430. European Union Citizenship. Eurobarometer, 2015. http://ec.europa.eu/justice/citizen/document/files/2016-flash-eurobarometer-430-citizenship_en.pdf (18.08.2016.), pp. 29-30.; 33. By the way, $75 \%$ of EU citizens were wrong believing that they are entitled to consular protection provided by any Member States' foreign service within the borders of the EU. Flash Eurobarometer \#430. European Union Citizenship, pp. 42-46. As for information on the available representations, citizens can use the following website which shall be kept up to date by the Member States - Consular protection for European Union citizens abroad: http://ec.europa.eu/consularprotection/index. action (29.08.2016.) or service Your consulates and/or embassies:http://europa.eu/youreurope/citizens/national-contactpoints/embassies/index_en.htm (29.08.2016.) which directs citizens to the consular website of the chosen State to get information on the State's foreign service.

29 Consular Directive, Article 9.

30 Consular Directive, Article 2.

31 Flash EB Series \#188 Consular Protection, p. 13. This is the latest survey on the topic.

32 Consular Cooperation Initiatives - Final report. Presented by the CCI Core Team to the EU Working Party for Consular Affairs COCON - 8. CFSP/PESC 345, 29 April 2016 Brussels, p. 3

33 ETD, Annex II. 4.

34 Consular Directive, Article 5. 
the costs incurred, as the cost are directly repaid by the Member State of nationality and then the reimbursement will be the matter of the State and its national under the scope of domestic rules. ${ }^{35}$

\subsection{Crisis preparedness: EEAS and its implication on consular law}

The Consular Directive makes special references to crisis situations which involves EU organs to the consular cooperation of consular authorities: the European External Action Service (EEAS) and its local delegations established under the terms of agreements between the EU and the Third State. ${ }^{36}$

EEAS was created to serve the High Representative to ensure more coherent and effective EU external action without any prejudice to the Member States foreign policy. ${ }^{37}$ Being part of the EEAS Crisis Response Department, the Consular Crisis Management Division currently has two roles: assisting the Presidency to coordinate consular policies across the EU (e.g. travel advice, issuance of consular guidelines), and to assist the EU Presidency and/or Lead States to coordinate action in times of crises. Delegations are placed under the authority of the High Representative of the Union for Foreign Affairs and Security Policy ${ }^{38}$ and support the Member States in facilitating cooperation and in helping them to help unrepresented citizens, but since consular protection remains a national competence, delegations do not provide direct assistance to EU citizens. So, the EEAS has contradictory mandates. It is expected to 'coordinate' (policies, institutions, member states, embassies, ministers, collective action, financial resources), provide leadership, and develop new ideas and policy entrepreneurship. But it is not supposed to challenge national foreign policy, to step on the toes of national diplomacies, or interfere with national priorities and interests. ${ }^{39}$

However, crisis is not defined by the Consular Directive; it is relatively obvious that the notion covers natural and man-made disasters which prevent or makes it impossible to apply the normal rules of consular protection while consular protection is needed more than ever. ${ }^{40}$ In the event of a crisis, the EU (EEAS and delegations) and Member States (representation) shall closely cooperate to ensure efficient assistance for unrepresented citizens. Within the framework of local cooperation, they shall prepare contingency plans to follow in such situations. Upon their request, Member States may be supported by existing intervention teams at Union level, including consular experts from unrepresented Member States. The protagonist of these situations is the (1) Lead State, the State or the Member State(s) coordinating and leading the assistance of unrepresented citizens during crises in any third country with the support of (2) the other Member States concerned, ${ }^{41}$ the (3) Union

35 Consular Directive, Article 14-15.

36 VAN VOOREN, B. - WESSEL, R. A.: External representation and the European External Action Service : selected legal challenges. CLEER Working Papers 2012/5, p. 79.

37 The establishment of an External Action Service "do not affect the responsibilities of the Member States, as they currently exist, for the formulation and conduct of their foreign policy nor of their national representation in third countries and international organisations." Treaty of Lisbon, 13. Declaration concerning the common foreign and security policy.

38 These are situations like Bali bombing in 2002, Indian Ocean tsunami in 2004, and 2006 evacuations from Lebanon or just from the recent past, terrorist attacks in Brussels, when citizens' life and security was threatened. TEU Article 32 al 3., 35. See, EEAS Decision, Article 5.

39 BALFOUR, R. - RAIK, K.: Equipping the European Union for the 21st century, p. 13.

40 TINDALL, K.: Governments' Ability to Assist Nationals in Disasters Abroad: What Do We Know about Consular Emergency Management? In: Journal of Contingencies and Crisis Management, Vol. 20, No. 2, 2012, p. 102. The executive directive to HCA defines crisis as a situation created by extraordinary and exceptional circumstances, which affect or may affect a significant number of citizens and require immediate action of the consular service. HCD, Article 1/A c).

41 See, Consular Directive, (23). In details: Lead State Guideline. Council European Union guidelines on the implementation of the consular Lead State concept (2008/C 317/06) OJ C 317, 12.12.2008, pp. 6-8. 
delegation and the (4) EEAS headquarters, and the (5) local authorities of the Third State in which the crisis happened is also a key factor. Member States shall provide the Lead State or the Member State(s) coordinating assistance with all relevant information regarding their unrepresented citizens present in a crisis. Issues of citizenship, as a matter of fact, make it challenging to estimate the number of citizens that may need consular protection mainly in States with a strong history of immigration, like Canada, the USA or Australia for instance. ${ }^{42}$ Therefore, the number of Member States concerned is also an unpredictable factor.

However, the consular authority of the Lead State only joins forces and coordinates measures and may request reimbursement of expenses generated by this mission, but is not responsible to provide the consular services. ${ }^{43}$ Therefore, the cooperation and support of the background is essential: interoperability between consular staff and other crisis-management experts should be enhanced, in particular through their participation in multi-disciplinary crisis teams, such as those under the EEAS crisis response and operational coordination and crisis management structures and under the Union Civil Protection Mechanism. The EEAS and its delegations, in fact, cannot replace Member States' consular tasks. The EU has no power to do so as the protection of citizens is too much related to the notion of nationality which is a core competence of Member States. Practical reasons might occur to EEAS to practice consular protection in third States but at this stage of EU integration it is not yet possible and by the way, for acting within that competence, under the general rules of international law, the consent of the Third State would also be needed. ${ }^{44}$

To coordinate actions and share tasks, Member States' authorities should closely cooperate and coordinate with one another and with the EU, the Commission and the EEAS, in a spirit of mutual respect and solidarity. The way of collaboration is the secure website of the EEAS (Consular OnLine) where Member States are obliged to provide and continuously update information on relevant contact points in the Member States to ensure swift and efficient cooperation.

\subsection{Some legal questions of the application of EU consular policy in Third States}

The model sounds simple, cooperation and sharing of information is at the heart of the process. However, a few questions arise concerning information sharing mechanism which is the frame of the whole consular policy in third States. First and foremost: consular services on the territory of a State can be performed only with the previous consent of the State of territory. So, the margin for help of the State of nationality is limited even if it is willing to help its national in lack of representation in a Third State or wish to entrust another State to act on behalf, since this latter also requires the consent of the State of territory. Additionally, the mechanism operates with a wide range of personal data the protection of which is also a fundamental right acknowledged by the Charter. There are two types of cooperation in this context: (1) The classical legal assistance when the consular authority needs information from another Member State's authority in a concrete case which is to be handled, for example when the clearance of the citizen is needed by his/her national authority for the issue of an ETD. (2) The cooperation mechanism is, in contrast, a continuous data sharing process without exact prior request as information management process is based on EU rules. It should be based

42 TINDALL, K.: Governments' Ability to Assist Nationals in Disasters Abroad, p. 105.

43 Lead State Guideline, 5.4.

44 VCCR 2. 1. The establishment of consular relations between States takes place by mutual consent. 4. 1. A consular post may be established in the territory of the receiving State only with that State's consent. 
on legally binding sources to make the procedure predictable and transparent with clearly defined tasks and competences, aspects of responsibility, applicable law and finally: supervision and legal remedy. ${ }^{45}$ The Consular Directive does not serve as a general legal background for cooperating mechanism with such details; it just outlines the frames and remains silent on details and calls for further negotiation on the procedural aspects. In lack of general EU legislation, how shall this new consular protection policy be more efficient than the previous inter-governmental regime?

Consular authorities act as public authorities on behalf of their sending State and with their acts and decisions they affect the legal position and situation of the individuals, and finally, their fundamental right to consular protection in third countries. Therefore, legal remedy is crucial for its proper enforcement. ${ }^{46}$ In case of need, the consular authority decides whether consular protection is exercised and which measure shall be taken. Being the fact that the right to consular protection has become a basic right by Article $46 \mathrm{EU}$ Charter, the Member States are also obliged to ensure the review of the decisions of the consular authority. To protect a right created by European law, judicial remedy shall be available. The European citizen who asks for consular assistance from the authorities of another Member State, and receives a refusal which he/she considers unfair or discriminatory, shall have the possibility to appeal to a national judge capable of exercising judicial review of the contested administrative decision. ${ }^{47}$ The Hungarian Consular Act (HCA) for example enlists those consular protection functions which require authority act, and if a consular officer takes a decision of first instance, the Minister of Foreign Affairs is entitled to proceed on appeal, but as for denial of those kind of measure which do not explicitly require authority procedure (as not all the tasks and functions of consular protection are considered as authority procedure), no provision exists. ${ }^{48}$

Besides that, the Consular Directive does not give any guidance on double citizenship, for instance. The citizenship policy of the EU is flexible in favour of the citizens and definitely not following the 'effective citizenship' or 'genuine link theory." In case of both citizenships of EU States one would think that the forum decides upon the competent consular authority, but according to the case-law of the Court of Justice of the European Union (CJEU) the jurisdiction does not automatically rely on the forum. ${ }^{50}$ In such cases, which State shall provide for consular protection? Does the citizen have the right of forum shopping in favor of a more expanded consular assistance if he or she is aware of both Sates consular protection legislation? What is the obligation of the consular authority? Does the citizen with double nationality choose the competent national authority, and is the consular authority obliged to check whether a citizen has double nationalities? General principles like acting in good faith do not give enough rules for responsibility limits of the authorities taking part in the cooperative mechanism. And this guides us to another topic which is not discussed by EU norms.

45 Model Rules. Welcome to ReNEUAL - the Research Network on EU Administrative Law. http://www.reneual.eu/ (31.08.2016.), VI-3., VARGA, ZS. A.: Gyorsértékelés az európai közigazgatási eljárási modell-szabályokról. In: Magyar Jog, 2014/10, 2014l, p. 547.

46 "Everyone whose rights and freedoms guaranteed by the law of the Union are violated has the right to an effective remedy before a tribunal in compliance with the conditions laid down in this Article. Everyone is entitled to a fair and public hearing within a reasonable time by an independent and impartial tribunal previously established by law." EU Charter, Article 47.

47 BATTINI, S.: The Impact of EU Law and Globalization on Consular Assistance and Diplomatic Protection, p. 179.

48 HCA, Article 19 (7).

49 "I $t$ ]he mere fact that a national of a Member State is also a national of a non-member country, in which he is resident, does not deprive him of the right, as a national of that Member State, to rely on the prohibition of discrimination on grounds of nationality." Case C-122/96, paragraph 15.

50 GYENEI, L.: Kettős állampolgárság az Európai Unió erőterében. In: Iustum Aequum Salutare, IX. 2013, 2, p. 160. 
Organizational problem might occur in case of crisis when the EEAS and its delegation appear as players in the procedure along with the Lead State. State administration is hierarchical; the chief a consular authority is under the direction of its own State, in particular the Minister of Foreign Affairs. In a crisis when the cooperative mechanism starts its real operation, there are usually no exact legislative provisions for handling those situations, when the Lead State or the EEAS gives order to Member States consular authorities. In fact, the EEAS decision suggests that EEAS and delegations help Member States and are not superior to their consular agents, but since Member States are required to act in conformity with EU interests, even if foreign policy is still a domestic field in majority, general obligations mean a kind of determination of activity. What happens if EU organs representing EU interests collide with the Member State's foreign policy? Which is stronger: loyalty and solidarity towards the EU and other Member States or the domestic hierarchical order in administration and the foreign policy of the sending State in the Third State? The Consular Directive declares that it does not concern consular relations between Member States and third countries. ${ }^{51}$ But it tacitly does - when it obliges Member States to widen the scope of consular agent's activity to protect any EU citizens and non-EU citizen family members. Therefore, an effective protection requires a reflection on bilateral consular agreements with Third States but this is still awaited. It also calls the Member States' embassies or consulates to, wherever deemed necessary, conclude practical arrangements among themselves on sharing responsibilities for providing consular protection to unrepresented citizens. Insofar, since the existence of EU citizenship, no such arrangements have been made. So, again, why is this Directive better than the former intergovernmental regime? Now, involving the EEAS and delegations, the common consular policy might get an extra impetus by implicitly giving a primacy of common interests, but can it be required under the present competency rules? All these problems reveal the necessity of a European regulation of administrative procedural law, mainly in the field of administrative cooperation mechanisms which is even more important in case of a crisis and highlights the fact that the EU is expanding on foreign policy issues where it still lacks the necessary power and competence to reach direct results.

\section{CLOSING REMARKS OR WARNING?}

From the viewpoint of rationality and efficiency, as Balfour and Raik states, there are compelling reasons for transferring at least some of the functions of national diplomacies to the EU, rather than having numerous representations of Member States in Third States where the EU also has delegation and time and resources are spent on coordinating among authorities. It would make sense to have just one large EU delegation representing the whole Union, centralize at least some consular services and limit national missions to a minimum. ${ }^{52}$ For this, EEAS needs to be at the center of an emerging EU system of diplomacy, shaping it and not just being shaped, and it must create a new sense of unity. It is true, that CFSP rules introduced by the Treaty of Lisbon and the creation of the EEAS are supposed to stimulate an internal logic towards more EU integration and burden-sharing in foreign policy, ${ }^{53}$ but the Treaty of Lisbon also made it clear that the provisions covering the CFSP

51 Consular Directive, Article 1.

52 BALFOUR, R. - RAIK, K.: Equipping the European Union for the 21st century, p. 37-38.

53 BALFOUR, R. - RAIK, K.: Learning to dance to the same tune? The European External Action Service and National Diplomacies. European Policy Center, 17 January 2013. http://epc.eu/documents/uploads/pub_3231_learning_to_dance_ to_the_same_tune.pdf (31.08.2016.), p. 1-2. 
including relation to the High Representative the EEAS, will not affect the existing legal basis, responsibilities, and powers of each Member State in relation to the formulation and conduct of its foreign policy, its national diplomatic service, or relations with third countries. ${ }^{54}$ Anyway, the expansion of EU policies, the Europeanisation of non-European legal areas is a question of the future; now the actual challenges shall be faced which concern the detailed procedural rules of consular authorities' cooperation in order to make it conform to the requirements of good administration.

\section{Bibliography:}

AUST, A.: Handbook of International Law. Cambridge: CUP, 2010. 592 pages, ISBN: 9780521133494.

BALFOUR, R. - RAIK, K.: Equipping the European Union for the 21st century. National diplomacies, the European External Action Service and the making of EU foreign policy. FIIA Report 36, 2013; 67 pages. ISBN 978-951-769-v.

BALFOUR, R. - RAIK, K.: Learning to dance to the same tune? The European External Action Service and National Diplomacies. European Policy Center, 17 January 2013. http://epc.eu/documents/uploads/pub_3231_learning_to_ dance_to_the_same_tune.pdf (31.08.2016.).

BATTINI, S.: The Impact of EU Law and Globalization on Consular Assistance and Diplomatic Protection. CHITI, E. - MATTARELlA, B.G. (eds.): Global Administrative Law and EU Administrative Law. Berlin, Heidelberg: Springer-Verlag, 2011.

BECÁNICS, A.: Konzuli védelem és segítségnyújtás az Európai Unió perspektívájából. KARLOVITZ, J. T. (ed.): Fejlődő jogrendszer és gazdasági környezet a változó társadalomban. 2014. ISBN 978-80-89691-21-0. http://www. irisro.org/tarstud2015aprilis/index.html (02.09.2016.), pp. 25-30.

CARE Final Report. Consular and Diplomatic Protection. Legal Framework in the EU Member States. 2010. http:// www.careproject.eu/images/stories/ConsularAndDiplomaticProtection.pdf (18.08.2016.) ISBN 978-88-9057641-6. 701 pages.

Case C-122/96, Saldanha and MTS/Hiross, [1997] ECR, I-5325, paragraph 15.

$\operatorname{COM}(2009) 263$ final. Communication from the Commission to the Council, the European Parliament, the European Economic and Social Committee and the Committee of the Regions. Justice, Freedom and Security in Europe since 2005: An Evaluation of the Hague Programme and Action Plan. Brussels, 10.6.2009 COM(2009) 263 final.

Consular Cooperation Initiatives - Final report. Presented by the CCI Core Team to the EU Working Party for Consular Affairs COCON - 8. CFSP/PESC 345, 29 April 2016 Brussels. 29 pages.

Consular Directive. Council Directive 2015/637 of 20 April 2015 on the coordination and cooperation measures to facilitate consular protection for unrepresented citizens of the Union in third countries and repealing Decision 95/553/EC. OJ L 106, 24.4.2015, pp. 1-13.

Council Decision of 1995. Decision of the Representatives of the Governments of the Member States meeting within the Council of 19 December 1995 regarding protection for citizens of the European Union by diplomatic and consular representations. OJ L 314 , 28/12/1995, pp. 73 - 76.

Directive on family reunification. Council Directive 2003/86/EC of 22 September 2003 on the right to family reunification. OJ L 251 3.10.2003, pp. 12-18.

EEAS Decision. Council Decision of 26 July 2010 establishing the organisation and functioning of the European External Action Service. OJ L 201, 3.8.2010, pp. 30-40.

ETD Decision. 96/409/CSFP: Decision of the Representatives of the Governments of the Member States, meeting within the Council of 25 June 1996 on the establishment of an emergency travel document. OJ L 168, 06.07.1996, pp. $4-11$.

EU Charter. Charter of Fundamental Rights of the European Union. OJ C 326, 26.10.2012, pp. 391-407.

54 Treaty of Lisbon, 14. Declaration concerning the common foreign and security policy. 
Flash EB Series \#188 Consular Protection. DG Justice, Freedom and Security Survey, Eurobarometer, 2006. http:// data.europa.eu/euodp/en/data/dataset/S572_188 (18.08.2016.) 67 pages.

Flash Eurobarometer \#430. European Union Citizenship. Eurobarometer, 2015. http://ec.europa.eu/justice/citizen/ document/files/2016-flash-eurobarometer-430-citizenship_en.pdf (18.08.2016.). 96 pages.

GEYER, F.: The External Dimension of EU Citizenship. Arguing for Effective Protection of Citizens Abroad. CEPS, No. 136. July 2007, pp. 1-11.

Green Paper: Diplomatic and consular protection of Union citizens in third countries. Brussels, 28.11.2006, $\operatorname{COM}(2006) 712$ final.

GYENEI, L.: Kettős állampolgárság az Európai Unió erőterében. In: Iustum Aequum Salutare, IX. 2013, 2, pp. $157-168$.

HCA. Act XLVI of 2001 on consular protection. Hungarian Official Journal, 75/2001 (VII. 3.).

HCD. Directive 17/2001 (XI. 15.) of the Ministry of Foreign Affairs on the detailed regulation of consular protection. Hungarian Official Journal, 127/2001 (XI. 15.)

KRŪMA, K.: EU Citizenship, Nationality and Migrant Status: an Ongoing Challenge. Leiden: Martinus Nijhoff Publishers, 2013. 498 pages, ISBN 9789004251588

Lead State Guideline. Council European Union guidelines on the implementation of the consular Lead State concept (2008/C 317/06) OJ C 317, 12.12.2008, pp. 6-8.

Maastricht Treaty. Treaty on European Union. OJ C 191, 29.07.1992, pp. 1-110.

Model Rules. Welcome to ReNEUAL - the Research Network on EU Administrative Law. http://www.reneual.eu/ (31.08.2016)

Proposal for a Council Directive on consular protection for citizens of the Union abroad. COM/2011/0881 final 2011/0432 (CNS)

SCHIFFNER, I.: A diplomáciai védelem gyakorlásának eszközei, avagy a fogalom-meghatározás és az elhatárolás problémái. In: Acta Universitatis Szegediensis de Attila József Nominatae Sectio Juridica Politica, Tom. LXXII. Fasc. 18, 2009, pp. 523-544.

SCHIFFNER, I.: Az uniós polgárok konzuli védelmének lehetőségei a tagállamok gyakorlatában. In: Forum: Acta Juridica et Politica, Vol. 2. No. 1, 2012, pp. 169-186

SLOANE, R. D.: Breaking the Genuine Link: The Contemporary International Legal Regulation of Nationality. In: Harvard International Law Journal, Vol. 50, No. 1, 2009, pp. 1-60.

TEU. Consolidated version of the Treaty on European Union. OJ C 326, 10.2012, pp. 13-45.

TFEU. Consolidated version of the Treaty on the Functioning of the European Union. OJ C 326, 26.10.2012, pp. 47197.

TINDALL, K.: Governments' Ability to Assist Nationals in Disasters Abroad: What Do We Know about Consular Emergency Management? In: Journal of Contingencies and Crisis Management, Vol. 20, No. 2, 2012, pp. $102-114$.

Treaty of Lisbon amending the Treaty on European Union and the Treaty Establishing the European Community. OJ C 306, 17.12.2000, pp. 1-283.

VAN VOOREN, B. - WESSEL, R. A.: External representation and the European External Action Service : selected legal challenges. CLEER Working Papers 2012/5, pp. 59-82.

VARGA, ZS. A.: Gyorsértékelés az európai közigazgatási eljárási modell-szabályokról. In: Magyar Jog, 2014/10, 2014, pp. 545-555.

VCCR. Vienna Convention on Consular Relations, Vienna, 24 April 1963, 596 UNTS 261.

VCDR. Vienna Convention on Diplomatic Relations, Vienna, 18 April 1961, 500 UNTS 95.

VERMEER-KÜNZLI, A: Where the Law Becomes Irrelevant: Consular Assistance and the European Union. In: International and Comparative Law Quarterly, 2011, vol. 60, pp. 965-995.

WESSEL, R. A.: Can the EU Replace its Member States International in International Affairs? An International Law Perspective. In: The European Union in the World: Essays in Honour of Marc Maresceau (Govaere, I. - Lannon, E - van Elsuwege, P. - Adameds S. eds.). The Hague: Martinus Nijhoff Publishers, 2013, ISBN 978-90-04-25904-8, pp. 129-148. 


\section{Contact information:}

Erzsébet Csatlós, PhD, senior lecturer

csatlos.e@juris.u-szeged.hu

University of Szeged, Faculty of Law and Political Sciences,

Department of Administrative Law

Bocskai u. 10-12.

6721 Szeged, Hungary 